\title{
Democracy in Postcolonial Africa: Imitation, Adaptation and Re-Creation
}

\author{
Oumarou Mazadou \\ Department of Philosophy, University of Yaoundé I, Yaoundé, Cameroon \\ Email: elhadjmazadou@gmail.com
}

How to cite this paper: Mazadou, $\mathrm{O}$ (2022). Democracy in Postcolonial Africa: Imitation, Adaptation and Re-Creation. Open Journal of Philosophy, 12, 1-20.

https://doi.org/10.4236/ojpp.2022.121001

Received: December 23, 2021

Accepted: February 7, 2022

Published: February 10, 2022

Copyright $\odot 2022$ by author(s) and Scientific Research Publishing Inc. This work is licensed under the Creative Commons Attribution International License (CC BY 4.0).

http://creativecommons.org/licenses/by/4.0/ (c) (i) Open Access

\begin{abstract}
In post-colonial Africa, political rulers aimed at achieving national integration, unity and development for their peoples. Yet, the experience, several years after the independence, is at the same time bitter and thought-provoking. Nationalism has failed to be the real finality of political power in most African countries and Democracy itself has still been in the making so much so that African states have the unfortunate reputation of being bad learners from the Western democratic experience. The African experience is that of the persistence of tribal, ethnic or clanic-based considerations over the national interest. This paper aims at rethinking democracy in Africa in view of suggesting a new form of Democracy that is compatible with the traditional organisation of our peoples. Only such a model of government will lead our nations towards Good Governance. Often decried as being outdated and for discriminating against women, traditional chieftaincy still plays a major role in Africa. Because of their proximity to the population, traditional leaders have a strong impact on social cohesion, particularly through traditional mediation. Drawing on the state of governance in Africa, this paper argues that traditional chieftaincy needs to be reinstated and that institutions in Africa need to be reinvented in such a way as to integrate tradition, which is a fertile foundation for peace.
\end{abstract}

\section{Keywords}

African Democracy, Tradition, Imitation, Adaptation, Re-Creation

\section{Introduction}

More than sixty after their independences, most African countries have sought to establish political systems inspired by the Western model of Democracy. Although some African countries have been singled out and ostracized by the in- 
ternational community for their democratic deficits resulting from endless political crises, today, few countries dare claim not to be democratic. According to Goyard-Fabre (2010: p. 1), in the age-old trilogy of political regimes: monarchy, aristocracy, democracy, the latter is defined, according to etymology, as "the power of the people". An apparently clear definition which, however, is a knot of difficulties. In their polysemy, the concepts of "power" and "people" are fraught with a lot of confusion and misunderstanding. Their one-dimensional definition is impossible and, in their pluralist approach, they do not have the same semantic resonance in antiquity, the modern world and the present time. If we could allow ourselves to extend Simone Goyard-Fabre's thought we would add to its diachronic dimension, which she only envisaged, the synchronic dimension, which would also concern the deployment of democracy in space. This is, in any case, the project that this reflection proposes to carry out, which will deal more specifically with the situation in Africa. The modalities of this exploration will mainly focus on the problem of imitation or the application of the Western ideal-type underpinned by a dynamic of universalisation, and on the problem of the resurrection of the forfeited paradigms of the African tradition or their adaptation to modernity. As a matter of facts, democracy in Africa, when considered with the Western lenses, appears as a failure with the lack of alternation, the handing-over of power from father to son (Gabon, Togo, Congo DR and recently, Chad), mismanagement of public wealth, Human Rights abuses, etc.

As it is observed, the international community, which was originally permissive on the political management of states, has now made democratic legitimacy a condition for the recognition of governments. There are numerous political, social, economic and institutional crises which have led to revolutions or popular uprisings, rebellions and, worse still, military coups. The series of coups, decried forms of undemocratic access to power, but unfortunately popular in predominantly francophone African countries, have marked the history of these countries since their accession to international sovereignty. As Biléou SakpaneGbati remarks, while the 1960s were considered to be the era of independence and single-party regimes characterised by opaque, partisan or clan management of state affairs, the 1990s, on the contrary, were synonymous with democracy, multipartism and a series of national conferences that were to serve as transitional frameworks for states towards democracy, through the re-foundation of republics that were highly troubled at the time by popular demands for democracy (Sakpane-Gbati, 2011: Section 2).

Unfortunately, the debates that were supposed to be constructive gave way to lies, despotism, slander, and hateful or even tribal discourse. These events have contributed to the deterioration of the political climate, the accentuation of personal, political and even ethnic divisions, and the maintenance and radicalisation of the dictatorial regimes that emerged from the single parties, which have become strong parties that have nothing to envy the single parties of yesteryear, with a backdrop of a plurality of small parties, most of which have no national scope. The fruits have not kept the promise of the flowers! Subsequently, politi- 
cians have de facto broken the climate of trust between themselves and between them and the population due to the unreadable game of unnatural alliances that are made and unmade according to the political situation. The recent turbulent history of the continent, with its difficult alternations, raises a question. Is it necessary to reinvent "an African-style democracy" and a political life that inspires confidence and pride? Given all the above-mentioned controversial political realities on the continent, is it possible to promote an African model of democracy in Africa that is peculiar to Africans, even if the methods of political governance seem at first sight to be anti-democratic? It is this question that we attempt answering by showing the relevance of reinventing a Democratic African experience today. Whereas Sakpane-Gbati (2011: Section 3) thinks that there is no need to reinvent a democracy and a political life because democracy is under construction and proposals for the consolidation of democracy and the cleaning up of political life already exist, we think that the failures of African Democracy rely on its incapacity of reflecting the cultural realities of our peoples and therefore it needs to be reinvented.

From an epistemological point of view, the aim of this paper is to proceed with the articulation of democracy and traditional power in a diachronic perspective that would integrate both traditional data relating to the conception of political power and contemporary realities. The central hypothesis is based on a twofold question: firstly, on the possibility of a meeting point or a constant tension between the two; secondly, on the influence that traditional power could exert on modern democracy with a view to an understanding or a better conception of political power in the perspective of finally shedding light on the very question of the essence of this power. The analysis in this case is topical and aims to bring out the deep motivations of these political structures.

We want to question these multiple motivations at the heart of a world, better said, an Africa, which is clearly distressed by both the visibly despotic drift of traditional power and the apparently chaotic overflow of modern democracies. The relationship between man and traditional power therefore appears compromising, while with democracy it leads to total despair. What is to be done in this case? Should we renounce the practice of these two modes of power? What critical thinking should be done about them? We are therefore dealing with the fact that man is torn between these two contradictory tendencies, and also with his desire to try to transcend this difficulty in order to understand the essence of political power. The role of the critic at this level is not to lock himself into the status quo, but to take the reflection beyond the "ready-made" solutions and those rooted in the past, to propose new ways of reading African political reality. Long before us, some African political theorists, such as Kwame Nkrumah, Julius Nyerere and many others, had already undertaken such a reflection by denouncing the dominant Western ideologies in Africa in the wake of independence. However, the choice of this theme is not accidental. The particularity of this work lies in the fact that it stigmatises and denounces the "ready-made" 
policies resulting from an alienated and alienating consciousness in contemporary Africa, in the face of the evolution of a world made up of upheavals of all kinds and radical questioning. These "ready-made" policies are invested with a powerful tendency to slavish imitation, through the reproduction of consumer habits, thought patterns, the imperialism of exogenous knowledge and research tools not adapted to the African environment. What then is the ontology, i.e. the true-being of politics in traditional Africa? To what extent can development and the solutions that flow from development policies be adapted to the African physical, sociological and political environment? In other words, is the creation of an eclectic model of the political not feasible in the updating of the African continent, which is already behind in several necessary adaptations?

\section{Western Democracy: A Universal Presumption Calling for Imitation}

The presumption of the universal character of Western democracy, with a tendency to self-proclaim, stems not only from its classical definitions since Antiquity, whose rationality could only destine them to this universality, but also from the very process of its advent. Almost everywhere in the West, democracies have appeared as the outcome of a revolutionary process: first in England, then in the United States and finally in France. It is as if all kinds of despotisms or absolutisms were essentially "democratizing". According to Aberdam (2014: p. 1) the French Revolution brought about for the first time a political model based on the participation of the greatest number. It was in the relationship between expressed social needs and the collective forms of citizens' assemblies that its capacity to resolve major social issues resided. In doing so, it created a tradition of democratic participation that has continued ever since. The liquidation of the legal basis of the privileges, power and wealth of the first two orders, the clergy and the nobility, was the great affair of the years 1789-1793, during which successive waves of peasant "jacqueries" shook all regions.

At the same time, craftsmen and wage earners in the cities began to demand not only equality of personal status and freedom to come and go, to work or to strike, but also the beginning of social rights, the right to eat for all and to live in all seasons. In the West Indies, the slave revolts raised the same questions, but in a much more bitter way. Finally, women had begun to demand and obtain civil rights, and then civic rights, while encountering vigorous resistance, especially from the autumn of 1793. This extraordinary flowering of movements and demands can be explained by the invention of forms of popular expression and self-organisation on a scale never seen before. This activity of the masses, characteristic of the first French revolution, with its ups and downs, remained active, extraordinarily so, for ten years or so. Moreover, in order to really put an end to it, a new type of state had to be built around the prefects and the gendarmerie, a state so powerful that it is, for the most part, still in place today.

Ahmut (2014) makes the same point in his book La Révolution française et la 
naissance de la démocratie électorale. Based on two decades of research in the national archives, those of all 83 departments created in 1789 and numerous municipal archives, the National Library and local archives, this book reaffirms the place of the French Revolution as one of the ancestors of modern democracy. From the elections of the Estates General to Napoleon's plebiscite, millions of citizens voted in some twenty consultations during the revolutionary decade. And the same is true of the earlier English revolution, when the British people granted themselves every right against absolutism, including that of habeas corpus, in 1243, long before the revolution itself. The Americans were no exception to the rule either, when they emancipated themselves from British rule in 1778.

The "Arab Spring" can also be called upon in this demonstration, as recent evidence. Tunisia, Libya and Egypt are the three countries in the Arab world that have managed to make their revolution and establish democracy after overthrowing a power that was considered dictatorial or, in any case, oppressive. In sub-Saharan Africa, we can also mention three very recent experiences, which are still waiting for the confirmation of time but which did not need bloodshed: the "citizen's broom" in Burkina Faso, then, by constitutional mechanism, the departure demanded by the people, of the heads of state of Zimbabwe and South Africa, both in 2018. These are three peaceful revolutions.

Does the fact that the Third World, and Africa in particular, has emerged from colonial rule mean that democracy has taken hold there ipso facto? While it is difficult to say whether democracy has taken hold, it can at least be said that there has been greater freedom, through the formal reality and the historically undeniable fact of independence, after which all that remained for each state was to decide on the form of its power. At that very time, at the time of independence in the 1960s and 1960s, Africa, forgetting the non-alignment recently adopted at Bandoeng in 1955, was divided into two parts according to the bipolarity that characterised the world at the time: on the one hand, the group of states opting for the system of liberal democracies, known as the "Casablanca Group", and, on the other, those that had opted for the socialist ideology of either Chinese or Soviet allegiance. The complexities that may have arisen at that time have faded in the present day in view of the one-dimensionality that now characterises so-called neo-liberal globalisation. This globalisation has not failed to define its criteria for good governance, which Africa has only to comply with, or in any case to undergo or imitate, in order to survive, unless it creates its own path as advocated by Gaddafi (1975), a path that is neither capitalist nor socialist, an anti-imperialist path that is free from all alienating mimetism.

\section{African Democracies Today: A Process of Adaptation}

Today, all political regimes in Africa, whether socialist, Marxist or liberal, seem to have failed: Benin's Marxist regime, Senegal's socialism, Mali's African socialism or Tanzania's UJAMAA. However, how did Africa arrive at this Westerncentric vision, making Western pluralist democracy the one and only form of 
political regime that is imposed on all societies, while denying all forms of nonWestern political cultures?

The exogenous reasons for the democratic transition are the result of the "winds from the East". These are in fact the socio-political upheavals that took place in the countries of Eastern and Central Europe around 1989-1990. These upheavals pushed the countries of the former communist bloc to switch to a market economy and to liberal and pluralist political regimes. It is through this political change that the countries of West and Central Africa will be influenced by this global convulsion. The fall of communism in the East will inspire the countries of the South, where those in power are irremovable potentates, bearers of all forms of sacredness. This will lead to demonstrations by populations demanding an end to autocracy and the establishment of pluralist democratic regimes. Thus, the fall of the leaders of the East will lead to the death of the dictatorial leaders of the South, and the shaking of totalitarian regimes in Africa. To this end, African leaders will be obliged to negotiate, to put themselves on the table for discussions with civil society, which is the advocate of the lower classes. Also, if the "East wind" has driven the democratisation movement in Africa, action in this part of the world has only been possible for internal reasons, due to accumulated frustrations.

In fact, the internal demands are made by internal forces that are eager for change, in a socio-political and economic environment dominated by a restriction of freedoms. In other words, the marginalisation of civil society, the predominance of neo-patrimonialism with the blessing of the single party, and above all the almost total absence of the people in the management and control of power, all of this will provoke an awakening of the collective conscience and a general mobilisation to demand the establishment of a multiparty political system. The respect for fundamental human rights in terms of opinion and ideological choice led to the emergence of several human rights organisations in Cameroon in 1991. Certain media like the magazine "Le Messager", became the place par excellence for the expression of the people's anger, to put pressure on the autocratic power and denounce the informal state. Faced with the reluctance of the government to respond favourably to all these demands, Cameroonian civil society, with leaders such as Mboa Massock, launched the "black towns" operation with a view to paralysing the country's major cities. All these movements of demands were to constitute an internal vector for democratic opening, although certain regimes, like the New Deal of Paul Biya, since he took power, gave a democratic impetus to his political action from his general policy speech to the National Assembly when he was sworn in on 6 November 1982. He declares: "I therefore call on all Cameroonian forces, without discrimination, for the happy advent of this political society that we want to be more open, more tolerant and more democratic" (Biya, 1986: p. 152).

Without denying that the democratic opening is endorsed by the speech at La Baule, for African countries, it is worth noting the manifestation of the will of 
certain regimes like Paul Biya's "New Deal" which has a lot of similarities with Mikhail Gorbachev's "Perestroika" and which, well before La Baule, had unveiled the colours of the democratic opening for its political action. On the strength of this, the Cameroonian "New Deal" and the Soviet "Perestroika" constitute two great political ideas that break away from one-party rule. Their rise has an impressive historical tone. However, what are the causes of their emergence?

Subscribing to the ideal of African hospitality, which recommends giving way to the foreigner, we will start with Perestroika. Perestroika is a political movement born in the former USSR in the mid-1980s, under the impetus of Mikhail Gorbachev, who became head of the Kremlin as First Secretary of the Communist Party and Head of the Soviet State. According to Hubert Mono Ndjana, it is known that Perestroika, at its inception in 1985, was essentially defined as economic restructuring. Mikhail Gorbachev was then outlining the development of Soviet society. Power as such was not then considered in this restructuring, except in an allusive way when he said in the same text that it was necessary to make the whole system of political and social institutions more active, to deepen socialist democracy and self-management (Mono Ndjana, 1992: pp. 84-85). It was only later that Gorbachev's originally economic concerns shifted to the political field. What about the Cameroonian New Deal?

With Hubert Mono Ndjana, we can retain that the New Deal is thus a renewal understood in the sense of purification. Or better still, a surpassing or perfecting of positive achievements for the purpose of social regeneration (Mono Ndjana, 1992: p. 87). The Cameroonian New Deal is a political movement born in 1982 under the impulse of Paul Biya. This movement shakes up certain retrograde reflexes known in the former regime. As such, says Paul Biya, I have also defined the main axes of the societal project that underpins the New Deal: rigour and moralisation, liberalisation and democratisation, a new style of state and party activity, and a new dynamic (Biya, 1983: p. 236).

Thus, the New Deal appears as a space that is structured by rigour, moralisation, liberalisation and democratisation. In many respects, the terms used by Mikhail Gorbachev and Paul Biya are indeed part of the same political and semantic universe. In the opinion of Hubert Mono Ndjana, it can be observed that the profound renovation of the party that Gorbachev speaks of, as well as the continuous democracy that he evokes, are a perfect echo of Paul Biya's thought, when he writes that in a word, it is in the final analysis, a profound change in national life that history has been calling for since November 6, 1982, a change to be carried out resolutely and in close collaboration with the people, but also to be carried out in a spirit of responsibility and method in order to gradually give birth to a more authentic democracy and a more open society (Mono Ndjana, 1992: p. 88). This leads Hubert Mono Ndjana to the conclusion that, there is correspondence, term by term, between profound renovation and profound change, between continuous democracy and that which will be born progres- 
sively.

In the Cameroonian political arena, this change was reflected not only in the effective plurality of candidates for the various elections, but also in the freedom of the press. These changes mark a revolutionary turn compared to the landscape of the former regime, where the discourse was one-dimensional. At this stage, if the transition implies a process, can we say that the action that was begun has continued or has it not served to mask, or rather to conceal, an even more totalitarian reality? In other words, despite these political upheavals, has the test of democratisation been a success or a failure?

All the states of sub-Saharan Africa have turned to economic liberalism, applying a policy developed under the auspices of the Breton-Woods institutions, namely the International Monetary Fund and the World Bank. To this end, even if the wave of democratisation movements that Africa has experienced since 1990 has been able to channel and resurrect long-suppressed hopes, the current political picture in Africa forces us to note that democracy remains elusive and betrays dreams that, at the outset, seemed to be high hopes.

In this respect, the situation of democracy in Africa is confused and deplorable, to say the least: procrastination here, jolts there. Each leader has carved out his or her own prototype of democracy like a ready-made suit. This gives rise to multiple interpretations and names: "packaged democracy", "rigged democracy", "transit democracy", "chameleon democracy", "softened democracy", "appeased democracy". In any case, this political regime is in pain. Eboussi Boulaga (1997), through the notion of "transit democracy", retraces the political reality in Cameroon from the 1960s to the 1990s. The philosopher seems to enlighten us on the democratisation process in Cameroon. Thanks to his analytical severity, Fabien Eboussi reveals the underside of political practice in Cameroon. By focusing on the assessment of the issues at stake in democratic transitions, he comes to the conclusion that there is a democratic vacuum, hence the expression "transit democracy". Thus, according to him, what is called democracy is only a succession of political assassinations disguised as heinous crimes, punitive expeditions of even peaceful demonstrations (Eboussi Boulaga, 1997: p. 71). As a result, there is a democracy that is set up as a bludgeoning of opinions and freedoms. The democratic transition in Cameroon has been nothing but a slogan, as the progress and improvements that have occurred since the beginning of the "transition" are almost insignificant. Far from being a sign of legislative and legal wealth, democracy was adopted in Cameroon to gain international recognition. All this is characterised by the brutality and insolence of the men in uniform who are in the pay of the government. Eboussi gives us a glimpse of this when he declares that the power in place is characterized by incompetence, corruption and voracity of the agents of the administration.

Yet, it is worth-noticing that the expression "transit democracy" used by Eboussi Boulaga does not reflect a reality specific to Cameroon. Transit democracy' is a political category specific to African states in general, in the aftermath 
of democratic transition movements. The social movements that marked the beginning of the 1990s in Africa did not carry real projects of social transformation. Thus, although the "East wind" was able to break some branches of political monolithism here and there, these branches grew back rather well. This is why, notwithstanding the concessions that may have been made (acceptance of the multiparty system demanded at the beginning of the 1990s, term limits), the institutions continue to function today as they did in the era of the single parties. Where the "demands" were able to obtain a constitutional limitation of the number of presidential terms, in order to hope and guarantee democratic alternation, the constitutions are increasingly modified. In this regard, Fabien Eboussi Boulaga also mentions Cameroon's dependence on France. This dependence is reflected in the complicity of the Cameroonian and French leaders, as evidenced by the agreements. Otherwise, how to explain the silence of France in the face of recurrent cases of human rights violations in Cameroon? In addition, the philosopher denounces the perverse effects of French aid for the structural adjustment of Cameroon. French aid, he believes, has prevented the Cameroonian government from having the political will to undertake reforms by guaranteeing it a survival that it could obtain by means of corruption and arms (Eboussi Boulaga, 1997: pp. 422-423).

Bad governance and its corollaries such as economic and post-electoral crises result from these various misinterpretations of ready-made democracy that each leader interprets and channels, in his or her own way, to maintain power. The modification of the constitution and the electoral fiddling through ballot box stuffing are only the consequence of this imported regime which does not suit the African environment. Still in the context of Cameroon, following Eboussi Boulaga, Zacharie Ngniman speaks in terms of "packed democracy". Thus, he writes that at the rate at which the economic crisis was growing in Cameroon, it was obvious that the current government was almost obliged to be unpopular, and that this unpopularity would remain for a long time the obligatory passage of successive regimes, with Cameroonians being called upon to make more sacrifices in order to straighten out the country (Ngniman, 1993: p. 248).

He denounces the underbelly of a harsh and merciless power struggle. As regards the first steps of the perilous democratic adventure in Cameroon, the country entered brutally into a democratic whirlwind. All these manoeuvres led to the holding of early legislative elections on 1 March and the presidential election on 11 October 1992. These were the first consultations under the seal of political pluralism in Cameroon for 30 years.

In Africa today, states have become attached to economic liberalism, while politically, their regimes are not attached to liberal ideals. Most of the leaders have adopted a regime that is economically liberal, but politically dictatorial. This is why democracy in Africa is flawed and subject to multiple interpretations. Each leader has established, as he or she pleases, a democracy like a tailor-made suit. In this democratic diversity, the qualifiers are divergent. Among 
others, we have: "advanced democracy", "peaceful democracy", "transit democracy" and many others. These are neither a carbon copy of traditional democracy, nor a monarchy, nor a carbon copy of modern democracy, but something plausible. These sclerotic, erroneous political regimes only make sense to serve the interests of potentates.

From the above analysis, it is clear that political Africa is at a crossroads. It is confused and in search of a saving political power that is slow in coming. It is an Africa that is completely lost, disoriented in the face of ready-made models that have difficulty taking shape and far removed from its ancestral methods, and can no longer resist. This is why Ondoua (2009) believes that in no way can the problems and challenges of democracy for the countries of the South be avoided or glossed over. If these problems revolve firstly around the rational management of basic identities, namely tribes and component communities, and secondly around the problem of development in the face of the dominant liberal model, how could this be possible?

In an Africa made-to-be-unmade-and-made-again, the creation of the future is an imperative to rethink democracy fundamentally in what it should be and not rather in what it is. Thus, Pius Ondoua opts for a "Plural Democracy". Plural democracy' implies that there are no fundamentals of democracy. And Pius Ondoua makes it clear in this sense: To speak of plural democracy refers to a radical critique of the dominant ideology, namely that the liberal-bourgeois form of democracy would be the best possible, unsurpassable, end/completion of the process of the historical evolution of the various societies (Ondoua, 2009: p. 25).

Thus, liberal democracy would be good in itself. However, if liberal democracy seems to be safe from any attack from external enemies, since it has absorbed its potential enemies, we would say that this ideology is not perfect. It poses serious problems in the case of the homogenisation of the world understood as globalisation. Such a policy consists of biting someone and blowing on the wound. Plugging the gaps in the social fabric contains all forms of inequality. By evacuating all alternatives, liberalism evacuates all dialectics. According to Pius Ondoua, it leads to a dedialectisation of history, with the ideological/material confinement and blockage that follows such dedialectisation. To evacuate any alternative is to arrest the whole planet, to impose the only instrumental form/ rationality in the ideological and material organisation of reality (Ondoua, 2009: p. 25).

Yet, since identities are plural, democracy must also be plural. To this end, if in any society there is a problem of legitimisation of political authority, one always asks, by virtue of what right do those who govern order and those who are governed obey? This question can be transposed to the planetary scale: by what right do those who drive the homogenisation of cultural identities impose a one-dimensional form of rationality?

Democracy cannot have a transcendent origin, nor can its legitimacy be based on its conventionality. As such, there is no such thing as a global democracy. 
The equality of nations in a supposedly united world is only a delusion. The dialectic of the absorption of certain weak cultural identities by the strongest is underway. How can we conceive of a planetary democracy, when the stratagems of exploitation through the world economy are intensifying? Democracy is a multifaceted and constant challenge. But how do we meet this challenge permanently? Pius Ondoua highlights a possible challenge for the individual. The individual is not naturally democratic; however, civic-democratic consciousness is a historical construction. He therefore considers that in the democratic city, it is not only in relation to political power that the individual becomes emancipated, it is first of all in relation to himself; it is then in relation to contextual limits/limitations; it is also and above all in relation to dominant, hypostasized ends, invested with truth and totality, without critical distancing having come into play (Ondoua, 2009: p. 91).

Consequently, education for citizenship inevitably implies the overcoming of individualistic closure, the recognition of the other, hence the concerted creation and management in all areas of existence. As such, we could tend towards a democratic catharsis by first focusing on the individual subject, before the institutional mechanisms take over.

From all the above analysis, we cannot therefore give a closed and definitive answer to democracy as a political category. It must be re-constructed, remodelled, permanently as it has been, since the historical trajectory initiated by Plato. With this radical recommencement, which leads to the questioning of man as the repository of reason, the essential questions of political philosophy are restated, first and foremost the question of legitimisation, universality and justice. To constantly make and remake Man is a never-ending task. In the absence of a standard model of universal democracy, can traditional African power not constitute a solution to the invasions of the great outside? Does it have the capacity to resist or can it simply appropriate the costumes in which the West has tried to formulate it? In other words, beyond the impossible resistance and adaptation of the old African power, which irreversibly plunges the black continent into an absence of direction, is the obligation of a new political deal not necessary?

\section{The Relevance of the Democratic Culture in Africa}

In the past, politics in Africa was characterised by the palaver. The palaver is therefore the place par excellence of politics. It created a real community of words. It is not only an exchange of words, but also a real social drama. The palaver indicates that man's being, before being substance, is relationship. It is characterised by the participation of all in debates on public matters and stimulates living together. For the Negro-African, reason remains the vigorous tool for understanding and orienting the meaning of human life, without any concern for transforming the real into the rational, or the existing into a concept. Reason appears as the matrix that gives rise to a vision of life, to a regulation of exis- 
tence. Thus, for the African, reason is only concerned with what is, and the meaning of what is, in order to clarify and restore an authentic human existence. It is for this reason that Negro-African thought is a doctrine of salvation, formulated once and for all by the sovereign ancestors, entrusted to the authority of the kings and elders of each people, transmitted and taught by the griots invested by the people and trained in the initiatory circles. Such a vision of the world is affirmed as a wisdom, a sapiential code, a vital message. This code of life is a concrete wisdom to be lived daily from generation to generation, in the traditional way. Ultimately, it consists of guiding the Negro-African to live according to a practical code of ethics with a view to establishing a humane world, where life is good. Negro-African thought is a thought of the useful, in short a functional philosophy.

The challenge of the palaver among the Negro-Africans is to establish harmony within the community by maintaining social ties and peace. Through its playful, theatrical and rhetorical aspect, the palaver is similar to a jurisdiction. This is all the more true because social evolution, which was very slow until the 19th century, allowed structures and customs to be preserved almost in their native state, to which all the old men or griots who received the sacred deposit by family profession can testify. However, the composition of this jurisdiction depends on each society. While in highly hierarchical societies, the court is presided over by members of the royal family, elsewhere it may be presided over by the champions of the initiation tests or by the oldest members of an age group. Being a judge implies holding an authority based on the sacred, but also on knowledge. Among the Beti of South Cameroon, the judge is called ntsig ntol, "the elder-trencher". The palaver is therefore a staging, setting in order and putting into words. Through the palaver, society questions its references, distances itself and can enter into an uninterrupted dialogue with itself. In the context of an agonistic palaver, i.e. following a dispute, asking for forgiveness does not consist in lowering one's authority. Rather, it is about reinserting it into the relationship with oneself. If the loser of the lawsuit has to compensate the plaintiff by giving him a goat, the latter has to kill it and give part of it to the loser's family. According to Bidima (1997), we can see that before the actual palaver is held, there are pre-palavers during which people who feel they have been wronged open up to a third party with influence that is recognised by both the accuser and the accused. Among the Béti, this complaint is made in several moments (mbémé) and the adjuration (évui son).

This does not prevent a discreet investigation from being carried out by mediators on both sides, with a view to gathering information by trickery and experience. This procedure, which characterised traditional and archaic institutional arrangements such as customary courts, is the embryonic form of democracy, its African version at village level. While it is recognised that democracy is of course familiar to African villages and tribes, the specificity of this democracy lies in the fact that it is held in an ordinary place. This is the space of the palaver. Godefroy 
Bidima writes that an ordinary place is thus set up as a signifying space, converted into an arena where the same and the other, the here and the elsewhere, confront each other through men. A place signified as a space is necessarily polemical, in that it makes it possible to distinguish the sacred from the profane, and the private from the public (Bidima, 1997: pp. 10-11).

From then on, we can unequivocally draw a parallel between the structure of "traditional chiefs and notables" and that of "heads of state and notables". Power was delegated, the people were associated with the management of the kingdoms, and there was already a form of election of chiefs in which the people lined up behind the candidate of their choice. The one who won the popular support was enthroned, as the example of the peoples of northern Togo shows. This organisational model was undermined by colonisation and decolonization (Sakpane-Gbati, 2011: Section 5).

In Africa, as in all traditional societies in general, palaver is found at all levels of civil society. Any occasion was a good opportunity to make meaning through words. There are several types of palaver that can be grouped into two categories: irenic palaver, which is held at the time of the marriage union between two individuals, particularly on the occasion of a sale. Agonistic palavers, which result from a conflict. This may be a land dispute, in case of flagrante delicto, or witchcraft. They consist in settling a dispute through language. The search for evidence is essential in agonistic palaver. There are five kinds of evidence: oracles, oaths, ordeals, testimony and the exercise of judicial duelling. These are used to remove the word from the arbitrary and to make the final verdict of the jury more weighty. Not all of this evidence is taken at the same time. Most often, evidence is required during the pre-trial phase. On the other hand, the evidence is expected during the trial. The oracle is always mediated by a diviner. This may take various forms depending on the type of society: the spider, the test of the sticks. The most fearsome oracle is the consultation of the corpses of individuals said to be possessed or of corpses.

Most often today, there is a tendency to define democracy by the election. This conception has never been the same in space and time, neither in the ancient democracies, nor in the doctrine of Jean Jacques Rousseau, the primordial element of democracy is defined by the election. Ancient democracies quite often preferred the drawing of lots to election. This process was based primarily on religious beliefs. To draw lots is to hand over the choice of rulers directly to the gods. By drawing lots, everyone has an equal chance of being elected to office. It was during the 19th century that the link between democracy and election began to be established.

Ancient democracies were essentially based on the direct participation of the governed in governmental decisions. The General Assembly of the people "Ecclesia" met every day on the hill of Sphinx called the "Agora". This was the driving force of democracy in Athens. As such, the African palaver is a traditional form of popular sovereignty open to all villagers, to whom the essential decisions 
belonged. It is through this grouping of the community governed by the mutual agreement of its members that nationalism was born.

The legacy of colonisation is that of "divide and rule" policy and ethnic withdrawal. If democracy is the dictatorship of the majority over the minority, how did ethnic minorities manage to take power and keep it in a context where ethnic or tribal cleavages, as in Libya, were created and maintained on purpose by the colonisers and then taken up again after independence by the presidential clans in order to continue to exercise power and to lay hands on the resources of their country? The borders resulting from colonisation did not take into account the limits of the kingdoms, and their populations found themselves dislocated between several countries, hence the need to work on the construction of new nations. If, with independence, there was a real desire to create nations, the failure is evident, since the ethnic, tribalist and especially regionalist vote is legion in Africa, as shown by the examples of the last presidential and legislative elections in Kenya, Togo, Côte d'Ivoire, Guinea, etc. It is practically impossible for a man from the south to be elected in the north and vice versa; in a given region, the ethnic factor predominates (Sakpane-Gbati, 2011: Section 6).

From the Palaver experience in the African past, we can reach the logical conclusion that Africa's inability to embrace democratic values is indeed a false belief. The affairs of the city were settled around "palaver trees" with the participation of the people or their representatives: it was time to legislate, to decide, to judge, to condemn, to educate and to sensitise the people. So Jacques Chirac declaration that "Africa is not ready for democracy" is false. The cultural barrier is often evoked to explain the difficulties encountered by Africa in its democratisation process. The culture of the chief that characterises African societies is said to be a poor receptacle for the embedding of democracy. In reality, this culture cannot be an obstacle to the emergence of democracy; this preconceived notion is erroneous (Sakpane-Gbati, 2011: Section 5). The problem is that when we talk about Democracy in Africa, we often use as criterion the western paradigm. Africa has experienced democracy in the past and is in need of building a model of Democracy that is not attached to the legacy of colonisation which divided a continent made up of great kingdoms into small states and has had as consequence the inability for African states to become real African nations.

\section{Towards a Cultural-Based African Democracy: The Need for Re-Creation}

Since all philosophy is the daughter of its time as Hegel said, it would not be possible to think of African political philosophy today outside of its geopolitical situation defined by its specific realities. Indeed, it must apply the conditions demanded by the masters of globalisation, generally referred to as the "international community". In order to benefit from the financing that is essential for their economy and social policy, African countries must first demonstrate good governance, by showing, with reports, how much they hold free and transparent 
elections, how much they apply the principle of democratic alternation at fixed periods, how much they encourage pluralism, how much they respect human rights and gender equality, how much they integrate the neo-liberal rules of the market, etc. It is this democracy that must be demonstrated, or nothing. That is, zero bilateral or multilateral funding. It is in this dilemma that the dignity and personality of our states are at stake, torn between submission/alienation involving juicy cooperation on the one hand, and national pride involving dereliction and the drying up of state coffers on the other. Sekou Touré had taken the Cornelian option of dignity in misery. But it only lasted for a short time, until he was liquidated.

If even Africa adopts the position of venal submission, that is to say, practising democratic alternations by imitating the inimitable model, it could only end up as a simple caricature because the two universes, the West and Africa, are not moulded in the same anthropological base. The Negro-African and the ArabBerber are the offspring of thousand-year-old traditions where power is a longterm process. The system of alternation, the periodicity of which is infinitely variable: five years here, six or seven years there, is therefore incompatible with the conception of a power of indefinite duration as conceived in Africa. Moreover, it is a functional duration, which, as we have seen in the West, allows the masters of society to consolidate the gains of stability and to build the basis for so-called modern institutional developments. The Western revolutions would have been nothing but hot air if castles, cathedrals and large cities as material frameworks of social life had not been established first. This functionality of duration is a millennial historical condition. Accompanied by intellectual misery and economic and material precariousness, revolutions in the Third World have only sunk into endless chatter and guerrilla warfare.

In their endeavour to conquer and dominate Africa, the Western colonial powers did not find anarchic and disorganised local powers, but stable powers, sometimes derived from ancient kingdoms or empires such as Mali, Songhai or Monomotapa, etc. The people were not absent from the machinery of power, since their grievances reached the strategic top through an institutional mediation that relayed messages in both directions. The people were not absent from the machinery of power, since their grievances reached the strategic summit through institutional mediation that relayed messages in both directions. These transmission belts had names specific to each culture, but with identical statutory missions: to convey messages in both directions of verticality and, above all, to control the supreme power, even if it meant decapitating it if circumstances required it to do so. Here, democracy was more radical and more effective without the need for tumultuous alternations. Thus, despite the imperial or monarchical, and sometimes despotic, display, it was indeed the people (Demos) who commanded (Cratein).

On this subject, we can read the very enlightening article by Quantin (2009), "La démocratie en Afrique: à la recherche d" un modèle", in which the author 
points out that by keeping the discourse on the possibility or impossibility of democracy at bay, Africa is not confronted today with a single imposed and rigid model, but rather has a set of different models that it can adapt according to the constraints that could confuse the outside observer. He observes that the study of democracy is usually careful to distinguish between models and experiences. The former are normative and set out what a democracy should be; the latter describe what actually happens in the establishment and practice of a democratic regime. Over time, models and experiences influence each other, but do not merge. There is nothing comparable in Africa: the experiences there give the impression of being exhausted in order to reach out-of-reach models without managing to stabilise into a specific and identifiable form that could form the basis of an original variety of democracy. On the contrary, the sum of practices accumulated following the numerous democratic transitions only serves to feed a long list of "adjective democracies", more or less diverted or unfinished forms of the contemporary Western model. These "adjective democracies", of which 550 varieties were already counted in 1997 throughout the world, describe numerous African experiences, for example: authoritarian democracies, neo-patrimonial democracies, guided democracies, illiberal democracies or even proto-democracies; they form a swamp in which efforts at classification get bogged down (Quantin, 2009: p. 65).

Many thinkers have therefore embarked on the pursuit of canonical models, that is to say, of a democracy without epithets, this kind of democracy whose paradigms were set out in La Baule in 1990, and which leads Africa to processes, always dictated by decentralisation, electoral transparency, the end of the buying of consciences, liberalisation supervised by the media, and the consolidation of the rule of law. This great moral framework should not be overlooked, as it is topped by institutional organisations such as the African Charter on Democracy and Elections (Addis Ababa, 30 January 2007), the ECOWAS Protocol on Democracy and Good Governance which, in its Article 2, Section 2, Chapter 1, prohibits the fraudulent modification of constitutions, and the Bamako Declaration of 3 November 2000, which lists the achievements, shortcomings and failures of democracy in order to propose solutions. This operational chronology is recalled by Sakpane-Gbati (2011) who comments that this arsenal of texts reflects that a substantial effort is being made, at least in a fairly theoretical framework, to find a good world to match the pressing and manifested aspirations of African peoples who are thirsty for democracy. The more or less violent demonstrations of Tunisians, Egyptians and Libyans have helped to put the question of democracy on the agenda in black African countries, via China and the major Arab monarchies (Sakpane-Gbati, 2011: Section 8).

As it appears, this thinker is still dealing with the problem of models and more or less successful adaptations of Western practices. One of the countries he cites in the final part of his text is, however, showing the way, perhaps in the general inattention of the paradigmatic break likely to free Africa from the democratic 
straitjacket: China, by solemnly and publicly overturning the dogma of alternation. The Cameroonian philosopher Mono Ndjana (2018), who has always advocated a long period in power for rulers in the process of laying the foundations and bases for a solid democracy, did not fail to return to the charge, on the occasion of the abolition of mandates in contemporary China. He writes that unaffected by the deafening pedagogy of democratic alternations, which are as untimely as they are destructive, and therefore counter-performing for underdeveloped countries, the other great power, China, has just burst the abscess of neoliberal hypocrisy by proclaiming the foreclosure of alternation, i.e. the principle of the durability of power and the indefinite re-electability of the head of state. This is an unadorned warning to the prevailing ideologies and, above all, to the chatter about good governance based on alternation (Mono Ndjana, 2018: p. 16).

According to Sakpane-Gbati (2011), Africa has made notable progress and setbacks that are part of the normal course of the democratisation process, which is more or less long depending on the specificities of the countries. With its many international, continental and regional agreements and treaties, Africa already has a fairly attractive framework conducive to the emergence of genuine democracies. The remedy already exists and is known to all: it will emanate from the will of the African political authorities to translate these various texts into reality. We would like to suggest that traditional chiefs have an important role to play in the political ruling of our countries and they must therefore be given not only an auxiliary administration power, but also a great political power.

Terence Ranger, an historian of colonial southern Africa, co-edited The Invention of Tradition with Eric Hobs-bawm. In his contribution, he examined the way in which British colonial authorities in southern Africa identified, organised and transformed existing ("traditional") forms of social organisation and used them to govern. He thus demonstrated the almost futile nature of any separation between the traditional and the modern (Ranger \& Hobs-Bawm, 2012). The state has been faced with "indigenous" political forms since colonial times. Above all, they have inspired policies that have swung between universalism and culturalism, between criticism and celebration (and instrumentalisation) of tradition. Deployed in very different local contexts, these policies have generalised "chieftaincy" across the continent. Under the model, realities differed greatly from one local sphere to another (Foucher \& Smith, 2011: p. 37).

While it is impossible to raise the question of powers that claim to be traditional outside of constructivist criticism, the fact remains that Africa still often holds the position of a reservoir of traditions in the Western imagination. Whether it is an obstacle or an opportunity, tradition is still for many commentators, both African and non-African, an indispensable category for thinking about Africa's destiny outside of history. It is in this line of thought that we would like to place tradition in the heart of African Democracy or African politics in general. As a matter of facts, most Africans give much more respect to their traditional chiefs than to the government. It is therefore necessary that the role of traditional 
chiefs be emphasised in policy making and in political rule. As chiefs continue to have influence and there are still obstacles to the smooth running of development projects, the development process would be facilitated by promoting the participation of chiefs.

There are different kinds of chiefs and chiefdoms in Africa. We focus on traditional chiefs whose positions date back to pre-colonial times, which give them a stronger legitimacy in the eyes of the population. The truth is that things change over time. Traditional leaders sometimes have to go through a sort of daily evaluation on their performance. Consequently, their power is weakened. The legitimacy of African chiefs has its origins partly in pre-colonial history, partly in religious beliefs and partly in culture. The origins of the contemporary state, on the other hand, lie in the judicial system, the constitution, nationalist struggles and democratic elections. In undertaking various kinds of development projects, the pre-colonial state may have tended to leave traditional leaders out of the equation. In our opinion, a good way to address this would be to put in place, where appropriate, mechanisms that enshrine the legitimacy of the state as well as that of traditional leaders, so as to encourage more citizens to participate in whatever development programmes are being undertaken. In this way, democracy will flourish, being nourished by the roots of culture and tradition.

\section{Conclusion}

At the end of this reflection which aimed at (re)conciliating, in one way or the other, African democracy with its cultural practices, we can say that politics deals with the better organisation of people lives. In order to achieve good governance, it is possible to root African Democracy on African cultural practices relating to power management. When Western Democracy insists on alternation as the true condition of Democracy and Good governance, the experience in most African countries is different. The principle of alternation at the head of the state is turned to its opposite: duration. We can only conclude that the will of the people is sometimes surprisingly variable and that this duration in power is somehow related to the cultural practices of African peoples. There, in the western world, the people are democratically determined for a specific period of time as an ideal paradigm. Here, in postcolonial Africa, a people, deliberating in a different way, tends to opt for the opposite paradigm of non-alternation, preferring stability and sustainability. Which is the more democratic choice, then, since it is the same formal source, i.e. DEMOS, in both cases? If the principle is therefore universal, namely that everything starts from the people, we must remember, from experience, that each people gives itself the power that best corresponds to its ETHOS, its culture, its history and its hopes. However powerful they may be, certain nations should not seek to impose their political frameworks and methodologies on others.

It is in this vein that we think that traditional chiefs who are usually called as mediators in times of conflicts must be given a constitutional political power in 
order to move African Democracy forward. They could be raised at the level of regional, divisional or subdivisional governors in order to fully play a political role as they are closer to their populations than the regional, divisional or subdivisional officers who are usually sent by the central state without at times being moulded in the cultures and traditions of the peoples they intend to rule. It is therefore clear that the will to universalise a model of democracy would, on the contrary, be the very negation of the democratic principle. Is not the acceptance of difference at this level a fundamental requirement?

\section{Acknowledgements}

We thank our Colleague, Dr. Denis-Ghislain MBESSA of the University of Douala (Cameroon) for the translation of this paper which was originally written in French.

\section{Conflicts of Interest}

The author declares no conflicts of interest regarding the publication of this paper.

\section{References*}

Aberdam, S. (2014). La Révolution française et l'apprentissage de la démocratie. https://www.europe-solidaire.org https://doi.org/10.3917/micha.bidim.1997.01

Ahmut (2014). La Révolution française et la naissance de la démocratie électorale (M. Edelstein et G. Knibichler, trad.). Presses universitaires de Rennes.

Bidima, G. (1997). La Palabre africaine, une juridiction de la parole. Michalon.

Biya, P. (1983). Le Message du Renouveau. SOPECAM.

Biya, P. (1986). Pour le libéralisme communautaire. Marcel Favre/ABC.

Eboussi Boulaga, F. (1997). La Démocratie de transit au Cameroun. Harmattan.

Foucher \& Smith (2011). Les aventures ambiguës du pouvoir traditionnel dans l'Afrique contemporaine. Revue Internationale et Stratégique, 81, 30. https://doi.org/10.3917/ris.081.0030

Gaddafi, M. (1975). La troisième voie. Le Livre Vert.

Goyard-Fabre, S. (2010). Les trois pouvoirs et la démocratie de Montesquieu au temps présent. https://academiesciencesmoralesetpolitiques.fr

Mono Ndjana, H. (1992). La Mutation, Essai sur le changement politique au Cameroun. Éditions du Carrefour.

Mono Ndjana, H. (2018). Abolition des mandats et durabilité du pouvoir. Le soleil se lève à l'Est. L'Estafette: Le mensuel de l'élite intellectuelle, 34, 26-42.

Ngniman, Z. (1993). Cameroun: La démocratie emballée. CLE.

Ondoua, P. (2009). Existence et Valeurs, Avenirs pluriels. tome 3, L'Harmattan.

Quantin, P. (2009). La démocratie en Afrique à la recherche d'un modèle. Pouvoirs, Revue française d'études constitutionnelles et politiques, 129, 65-76.

*This paper, originally written in French used the sources in French which were just translated in English. 


\section{https://doi.org/10.3917/ris.081.0030}

Ranger, T., \& Hobs-Bawm, E. (2012). The Invention of Tradition. Cambridge University Press.

Sakpane-Gbati, B. (2011). La démocratie à l'africaine. Revue Éthique Publique, 13, 1-12. https://doi.org/10.4000/ethiquepublique.679 